\title{
A Study on Readability of Selected Articles of Selected Farm Magazines
}

\author{
T. Archana*, K. Sailaja and K.B. Suneetha Devi \\ Department of Agriculture Extension, College of Agriculture, PJTSAU, \\ Rajendrangar, Hyderabad 500030, India \\ *Corresponding author
}

\begin{tabular}{|c|c|}
\hline & A B S T R A C T \\
\hline & \multirow{5}{*}{$\begin{array}{l}\text { Descriptive research design was followed for carrying out the study. The State of Andhra } \\
\text { Pradesh was selected purposively for the study as the investigator hails from the state. Out } \\
\text { of } 23 \text { districts of Andhra Pradesh, } 16 \text { were selected using sample random sampling } \\
\text { technique. Based on the criteria of highest circulation as well as the availability of the } \\
\text { subscribers for each of the farm magazines, three Telugu farm magazines were selected for } \\
\text { the study. They were the publications of Acharya N.G. Ranga Agricultural University } \\
\text { (Vyavasayam-I category) state department of agriculture (Padipantalu-II category) and } \\
\text { private agency (Annadata-III category), respectively as denoted. To study readability of } \\
\text { farm magazines three, hundred word samples were purposively selected from the 'others', } \\
\text { which was found to be commonly followed format of presentation (recorded high } \\
\text { frequency) from each of the three farm magazines. Thus, a total of nine, } 100 \text { word samples } \\
\text { from three farm magazines formed the sample to assess the readability. The findings with } \\
\text { regard to the level of reading ease of the three farm magazines were found to be 'very } \\
\text { difficult' with reading ease score of less than } 15 \text {. The findings with regard to level of } \\
\text { human interest in three farm magazines were 'dull' with human interest scores of } 16.87 \text {, } \\
20.74 \text { and } 19.19 \text { respectively. Level of human interest can be increased to 'dramatic' from } \\
\text { 'dull' through farmer-led journalism wherein farmers need to be encouraged to document } \\
\text { their experiences. }\end{array}$} \\
\hline $\begin{array}{l}\text { Readability, } \\
\text { Articles, Farm } \\
\text { magazines. }\end{array}$ & \\
\hline Article Info & \\
\hline $\begin{array}{l}\text { Accepted: } \\
\text { 10 July } 2017 \\
\text { Available Online: } \\
\text { 10 September } 2017\end{array}$ & \\
\hline & \\
\hline
\end{tabular}

\section{Introduction}

The increasing level of literacy in the rural areas offers new promises and prospects for the development of farm journalism. The utilization of print media is bound to increase manifold. This strategy reflects an assessment of the inadequacies of conventional farm journalism and the limited usefulness of many publications aimed at farm households. Farm magazines have been the vital source of providing detailed complete information in understandable form by the use of variety of graphic aids.

Indian agriculture sector is in transition from traditional to commercial agriculture. Modern agricultural practices and the relationship with environmental depletion is creating problem. Some of the developmental challenges faced by the Indian agriculture sector are illiteracy, poor socioeconomic conditions, lack of technical knowledge and awareness, small land holdings, modernization leading to barren land and disasters leading to rural poverty, weather-dependent farming systems, low per capita income, underdeveloped physical infrastructures and inefficient bureaucratic procedures associated with the comparatively high cost of agricultural production. Natural disasters and humaninduced environmental degradation are 
closely associated with improved farm-ing systems. These challenges can be attended through agriculture journalism.

Farm periodicals have great future in India for sustainable development of the rural areas. The effectiveness of the printed word in terms of its comprehension by the intended clientele would be substantially affected by how well the matter is organized and presented to them. Farmer as the real agricultural scientist who will experiment on different technologies in his field and will earn experience what is good or bad through 'learning by doing' and 'seeing is believing' approaches of extension. Various events or news on discoveries of a particular adaptive technology in the universities/research institutions/ government or semi government organizations/private organizations should be published in the farm journals in simple language and style.

The findings of the study will help the Agricultural Universities and other similar publishing organizers to adjust the contents of their published matter suitably for effective communication in future.

\section{Materials and Methods}

Descriptive research design was adopted for the study. A descriptive study is a sort of fact finding operation with adequate interpretation. It states clearly the characteristics of a particular situation or group or individuals in descriptive design and the variables are assumed to be known. Hence, the hypotheses are also formulated implicitly or explicitly at the level of statistical regularities descriptively.

Based on the criteria of highest circulation as well as the availability of the subscribers for each of the farm magazines, three Telugu farm magazines were selected for the study. They were the publications of Acharya N.G.
Ranga Agricultural University (Vyavasayam-I category), state department of agriculture (Padipantalu-II category) and private agency (Annadata-III category) respectively as denoted.

The term readability was expressed in terms of reading ease and human interest. It was operationalised as level of easiness with which article can be read. To measure this, average word length and average sentence length were considered as parameters.

The following criteria have been adopted for words, sentences, syllables, personal words and personal sentences.

\section{Word}

Anything surrounded by white space. All hyphenated words are counted as one word. Each letter, number or symbol is counted as a word.

\section{Sentence}

Each unit of thought that is grammatically independent of another sentence or clause and if end was marked by a question mark, semicolon or colon is to be counted as sentence.

\section{Syllable}

According to a book, exclusively dealing with Telugu gram-mar entitled "A modern Standard Telugu Grammar" a syllable is a vowel or a constant giving a vowel sound.

In Telugu language there are 14 vowels and 34 consonants.

\section{Human interest}

It was operationalised as level of human interest be-stowed in the articles published. 
The particulars used for human interest are per cent of personal words and per cent of personal sentences.

\section{Personal words}

The following are considered as personal words.

The personal words are all first, second and third person pronouns except the pronouns 'it' 'its' 'itself' and the pronouns 'they', 'them', 'their', 'theirs', 'themselves', referring to things rather than people.

For example, count the word 'them' as a personal word in the sentences 'when I saw his parents, I hardly recognized them', but not in the sentence 'I looked for the books, but I could not find them'. This is to say that 'them' refers to personal things like books it is not considered as personal word, unlike in other sentence wherein 'them' denotes personal word.

All words that have masculine or feminine gender, e.g. John, Mary, father, sister, actor and actress were considered as personal words. The common gender words like teacher, doctor, employees etc, should not be counted as personal words.

The group of words like 'people' and 'folk' should be counted as personal words.

\section{Personal sentence}

The following are considered as personal sentences.

Marked by quotation marks or otherwise often including speech tags like 'he said' set off by colons or commas. For example, he said 'I doubt it'.

Questions, commands, requests and other sentences directly ad-dressed to the reader.

\section{For example: Does this sound impossible?}

Three, hundred word samples were purposively selected from the 'others', which was found to be commonly followed format of presentation (recorded high frequency) from each of the three farm magazines.

Thus, a total of nine, 100 word samples from three farm magazines formed the sample to assess the readability.

Readability was measured according to the scale developed by Tulasiram (1982) in Telugu which was developed on the basis of scale developed by Rudolf Flesch (1951).

\section{Reading ease}

The two parameters of reading ease-the average sentence length and average word length were calculated with the help of the following formulae.

$$
\begin{aligned}
& \text { Average sentence Length }=\frac{\text { Number of words }}{\text { Number of sentences }} \\
& \text { Average word Length }=\frac{\text { Number of syllables }}{\text { Number of words }} x 100
\end{aligned}
$$

Reading Ease $($ R.E $)=206.835-0.846$ WL$1.015 \mathrm{SL}$

$\mathrm{WL}=$ Average word length

$\mathrm{SL}=$ Average sentence length

The level of the reading ease of the selected articles was known based on the scores obtained.

\section{Human interest}

The parameters for computing the human interest were per cent of personal words and per cent of personal sentences which were calculated with the help of the following formulae. 
Percents of personal words $=\frac{\text { Number of personal words }}{\text { Total number of words }} x 100$

Percents of personal sentences $=\frac{\text { Number of personal sentences }}{\text { Total number of sentences }} x 100$

Human Interest $(\mathrm{H} . \mathrm{I})=3.635 \mathrm{PW}+0.314$ PS

$\mathrm{PW}=$ Personal Words

PS $=$ Personal Sentences

The level of human interest of the selected articles was known based on the scores obtained.

\section{Results and Discussion}

The selected three articles of the three farm magazines were studied with reference to the aspects 'how easy and 'how interesting 'and the results are presented in Tables. 3 and Table. 4 respectively. It could be sensed from
Table. 3 that the level of reading ease of the three farm magazines was found to be 'very difficult' with reading ease score of less than 15.

Table. 3 revealed that the reading ease level was 'very difficult' in all the three farm magazines due to using of more number of syllables per hundred words and more words per sentences. This type of article can-not be read by the readers easily. Hence, the writers should reduce the syllables per 100 words and sentence length for easy reading of articles.

Moreover, these results can also be attributed to format of presentation in the three farm magazines which was mostly 'others' articles, without processing of the same (Table.2). This finding was in agreement with those of Nanjappa et al., (1998), Jagannathan and Reddy (1974).

Table.1 Standards of reading ease scores for Telugu literature

\begin{tabular}{|r|l|l|l|l|}
\hline S.No. & $\begin{array}{l}\text { Reading ease } \\
\text { level }\end{array}$ & $\begin{array}{l}\text { Average } \\
\text { sentence length }\end{array}$ & $\begin{array}{l}\text { Average word } \\
\text { length }\end{array}$ & $\begin{array}{l}\text { Reading } \\
\text { ease score }\end{array}$ \\
\hline 1 & Very easy & $<3.84$ & $<328.79$ & $>82$ \\
\hline 2 & Easy & $3.82-5.263$ & $329.79-338.9$ & $70-82$ \\
\hline 3 & Fairly easy & $5.263-6.685$ & $338.9-349.2$ & $55-70$ \\
\hline 4 & Standard & $6.685-8.107$ & $349.2-359.4$ & $40-55$ \\
\hline 5 & Fairly difficult & $8.107-9.529$ & $359.4-369.61$ & $28-40$ \\
\hline 6 & Difficult & $9.529-10.59$ & $369.61-379.8$ & $15-28$ \\
\hline 7 & Very difficult & $>10.59$ & $>379.8$ & $<15$ \\
\hline
\end{tabular}

Table.2 Standards of human interest scores for Telugu literature

\begin{tabular}{|r|l|l|l|l|}
\hline $\begin{array}{l}\text { S. } \\
\text { No. }\end{array}$ & $\begin{array}{l}\text { Human } \\
\text { interest level }\end{array}$ & $\begin{array}{l}\text { Percentage of } \\
\text { personal } \\
\text { words }\end{array}$ & $\begin{array}{l}\text { Percentage of } \\
\text { personal } \\
\text { sentences }\end{array}$ & $\begin{array}{l}\text { Human } \\
\text { interest } \\
\text { score }\end{array}$ \\
\hline 1 & Dull & $<13.372$ & $<25.698$ & $0-51$ \\
\hline 2 & $\begin{array}{l}\text { Middle } \\
\text { interesting }\end{array}$ & $13.372-16.315$ & $25.696-38.35$ & $51-66$ \\
\hline 3 & Interesting & $16.315-19.257$ & $38.35-51.002$ & $66-79$ \\
\hline 4 & Very interesting & $19.257-22.2$ & $51.002-63.65$ & $79-94$ \\
\hline 5 & Dramatic & $>22.2$ & $>63.65$ & $94-100$ \\
\hline
\end{tabular}


Table.3 Computation of level of reading ease of selected articles of three farm magazines

\begin{tabular}{|r|l|c|c|l|l|}
\hline S.No. & $\begin{array}{l}\text { Category of } \\
\text { farm } \\
\text { magazines }\end{array}$ & $\begin{array}{l}\text { Average } \\
\text { sentence } \\
\text { length }\end{array}$ & $\begin{array}{l}\text { Average } \\
\text { word } \\
\text { length }\end{array}$ & $\begin{array}{l}\text { Reading } \\
\text { ease score }\end{array}$ & $\begin{array}{l}\text { Reading ease } \\
\text { level }\end{array}$ \\
\hline 1 & I & 11.57 & 641 & $347.19(<15)$ & Very difficult \\
\hline 2 & II & 11.49 & 635.33 & $342.31(<15)$ & Very difficult \\
\hline 3 & III & 11.3 & 627 & $335.07(<15)$ & Very difficult \\
\hline
\end{tabular}

Table.4 Computation of level of human interest of selected articles of three farm magazines

\begin{tabular}{|c|c|c|c|c|c|}
\hline S.No. & $\begin{array}{l}\text { Category of } \\
\text { farm } \\
\text { magazines }\end{array}$ & $\begin{array}{l}\text { percent of } \\
\text { personal } \\
\text { words } \\
\end{array}$ & $\begin{array}{l}\text { percent of } \\
\text { personal } \\
\text { sentences } \\
\end{array}$ & $\begin{array}{l}\text { Human } \\
\text { interest } \\
\text { score }\end{array}$ & $\begin{array}{l}\text { Human } \\
\text { interest } \\
\text { level }\end{array}$ \\
\hline 1 & I & 2.33 & 26.85 & 16.87 & Dull \\
\hline 2 & II & 3.33 & 27.57 & 20.74 & Dull \\
\hline 3 & III & 2.66 & 30.35 & 19.19 & Dull \\
\hline
\end{tabular}

Data presented in Table. 4 revealed that all the three selected farm magazines i.e., I, II and III came under human interest level of 'dull' with human interest scores of 16.87, 20.74 and 19.19 respectively. Table. 4 revealed that the human interest was 'dull' in all the three farm magazines, which could be ascribed to the presence of less per cent of personal words and personal sentences in the textual matter of farm magazines.

These articles were not creating any interest among the readers.

The writers should increase the number of personal words and personal sentences in articles for creating the interest among the readers of farm magazines. This finding was in agreement with that of Reddy (1991) and Kumar (2003). The finding on readability revealed that level of reading ease was 'very difficult' and level of human interest was 'dull'. It was also suggested by the readers to have information presentation in short sentences to have 'very easy' level of reading ease. Trained writers and editors would better attend to this work. Level of human interest can be increased to 'dramatic' from 'dull' through farmer led journalism wherein farmers need to be encouraged to document their experiences.

\section{References}

Jagannathan, L., and Reddy, Y.N. 1974. A study on preparation, presentation and effectiveness of farm radio talk in Tamilnadu. M.Sc. (Ag) The-sis. Andhra Pradesh Agriculture University, Hyderabad.

Kumar, R.V., 2003. Readability, credibility and utility of Andhra agriculture journal- An appraisal. M.Sc. (Ag) Thesis. Acharya N.G. Ranga Agricultural University, Hyderabad.

Nanjappa, D., Ganapathy, K. R and Yogananda, H. G. 1998. Utility of agricultural information by the newspaper reader farmers of Bangalore district, their preferences, opinions and suggestions. Journal of Extension Education. 9 (1): 1919-1924.

Reddy, A. B., 1991. A critical analysis of printed farm publications with reference to their readability, credibility and utility. M.Sc. (Ag) Thesis. Acharya N.G. Ranga Agricultural University, Hyderabad.

\section{How to cite this article:}

Archana, T., K. Sailaja and Suneetha Devi, K.B. 2017. A Study on Readability of Selected Articles of Selected Farm Magazines. Int.J.Curr.Microbiol.App.Sci. 6(9): 3674-3678. doi: https://doi.org/10.20546/ijcmas.2017.609.452 